María C. Abuín Rouco and Guillermo Riesco Muñoz*

\title{
Influence of blue stain on density and dimensional stability of Pinus radiata timber from northern Galicia (Spain)
}

\begin{abstract}
The presence of blue-stain fungi considerably decreases the value of Pinus radiata timber, which is commercially important in Galicia (NW Spain). For this study, seven young pine trees growing in four different plantations were felled, and 20 discs were sampled from different heights in the stems. Parts of the discs were discoloured as a result of fungal infection. The discs were cut into small specimens. Defect-free specimens (controls) were selected for determining density and dimensional stability both in the volume and in the axial direction. Physical properties of fully blue-stained specimens and the controls were compared for each disc based on one-factor analysis of variance. As the factor was blue-stain, the other sources of variation were suppressed, such as tree source, height in the stem, ring width, cambial age and presence of heartwood or sapwood. Most of the physical properties analysed on some sample discs differed significantly between discoloured and unstained wood. The variables most affected by blue stain were basic density and volumetric shrinkage: blue-stained wood was $1.1 \%$ lighter and volumetric shrinkage was $5 \%$ higher in blue-stained wood than in the controls.
\end{abstract}

Keywords: axial shrinkage, basic density, blue-stain fungi, hygroscopicity, oven-dry density, Pinus radiata, properties depending on stem height, radiata pine, shrinkage, specific gravity, volumetric shrinkage

DOI 10.1515/hf-2014-0014

Received January 17, 2014; accepted April 4, 2014; previously published online May 10, 2014

\footnotetext{
*Corresponding author: Guillermo Riesco Muñoz, University of Santiago de Compostela, Department of Agroforestry Engineering, Higher Polytechnic School, University Campus, 27002 Lugo, Spain, Phone: 0034-982-823233, e-mail guillermo.riesco@usc.es María C. Abuín Rouco: University of Santiago de Compostela, Department of Agroforestry Engineering, Higher Polytechnic School, University Campus, 27002 Lugo, Spain
}

\section{Introduction}

Spain is fourth in the world in terms of hectares of land covered by radiata pine (Pinus radiata D. Don). The small dimension timber is mostly used as raw material in particleboard and fibreboard manufacturing. The abundance of sapwood and juvenile wood in small logs reduces wood quality (Fernández-Golfín Seco 1996; Jayawickrama 2001; Riesco and Díaz 2007). Blue-stain fungi (usually from genera Aureobasidium, Ceratocystis, Ceratostomella, Endoconidiophora, Graphium, Lasiodiplodia, Leptographium, Ophiostoma and Sphaeropsis) commonly appear in sapwood 5-7 days after felling (Forest Products Laboratory 2010). The fungi give the wood a grey-bluish colour and reduce its economic value (Kollmann 1959; Torres Juan 1964). The decline in value is higher in wood used for decorative purposes than for structural applications (AENOR 2008; AENOR 2011). Recent works aiming at biological control of sapstain fungi (Gradinger et al. 2009; Hong et al. 2014) or combating fungi colonisation by quat- and amino-silicones (Ghosh et al. 2012) showed the importance of the research in this field.

Blue staining can be avoided if the moisture content (MC) in sawn planks is quickly reduced by kiln drying or by slower drying combined with treatment with preservatives.

Physical properties in wood affected by blue stain are not substantially modified, with the exception of stability in the axial direction (Rey Prieto and Riesco Muñoz 2012), and hygroscopicity and permeability if the fungal attack is intense and affects mature wood (Kollmann 1959; Torres Juan 1964; Rodríguez and Arriaga 1988; McFarling and Byrne 2003; Byrne et al. 2005; Vignote and Martínez 2006). Byrne et al. (2005) reported the lack of references on the influence of blue stain on the properties of solid wood and it is also emphasised that most studies reported that blue stain does not affect wood from temperate areas.

The aim of the study was to determine the effect of blue stain on density and dimensional stability (shrinkage properties) of solid wood from young radiata pine trees. 


\section{Materials and methods}

Wood was obtained from seven young and apparently healthy Pinus radiata D. Don trees felled in four plots located in northern Galicia. The characteristics of the sampled pines are listed in Table 1 . They were in the first third of the usual rotation for the species; i.e., 30-35 years according to Fernández-Golfín Seco (1996). The number of sampled trees met the requirements of European Standard EN 384:2010 and Spanish Standard UNE 56528:1978 (AENOR 1978a) for testing small defect-free wood specimens. Cross-section discs (slabs) of $10 \mathrm{~cm}$ thickness were cut from each felled tree beginning at the base and then every metre to $6 \mathrm{~m}$ up the stem. The discs were maintained under laboratory conditions until approximately half of the cross surface of the discs was discoloured by blue-stain fungi. The discs were then cut to obtain the maximum number of small prismatic specimens with target dimensions $2 \times 2 \times 4 \mathrm{~cm}^{3}$ in the $\mathrm{R}, \mathrm{T}$ and $\mathrm{L}$ direction, respectively (AENOR 1978a). The breakdown of the discs, made when the degree of blue stain was sufficient to yield a similar number of stained and unstained specimens in each disc, did not take into account the MC of wood at the time. As a result, tested specimens exhibited MCs varying around the standard value of 12\% (AENOR 1978a), although further analyses revealed that the variation was negligible.

The specimens with both ends completely stained $\left(\mathrm{W}_{\text {stained }}\right)$ or completely free of stain $\left(\mathrm{W}_{\text {not st. }}\right)$, were selected for tests. The intensity of stain was not considered but its spreading in the heads. Specimen cross sections were only examined because the stain is less visible on the sides of the samples (Kollmann 1959). The criterion of visually checking the spread of blue stain on the specimen heads was adopted because of its easy application under practical conditions in the mill.

No trace of bark or pith was included to avoid the periphery or the centre of the disc. Thus the possible influence of compression wood (usually located near the pith) was eliminated. The comparison of physical properties between $\mathrm{W}_{\text {stained }}$ and $\mathrm{W}_{\text {not st. }}$ was made separately for each disc to avoid the significant inter-tree and along-tree variation as sources of variation (Kollmann 1959; Zobel and Van Buijtenen 1989; Kininmonth and Whitehouse 1991; Riesco and Díaz 2007). Heartwood as a possible source of variation was discarded because heartwood formation begins after 12-15 years (Fernández-Golfín Seco 1996) and the age of the sampled trees was 13 years on average.

On average 37 specimens per tree were selected and tested according to the Spanish Standards UNE 56531:1977 (AENOR 1977a), UNE 56532:1977 (AENOR 1977b), UNE 56533:1977 (AENOR 1977c), UNE 56528:1978 (AENOR 1978a) and the International Standards ISO 3131:1975, EN 13183-1:2002 and EN 408:2011. The mass of each specimen was measured to the nearest $0.01 \mathrm{~g}$ and the three main dimensions were obtained between centres of opposite faces, to the nearest $0.01 \mathrm{~mm}$. The volume was obtained by considering each specimen as a prismatic piece and multiplying the three main dimensions. The discs were cut when they were fairly dry to avoid fibrous surfaces in case of wet sawing, which leads to irregular faces and errors. The physical properties (listed in Table 2) were measured after cutting the discs. The basic density was calculated as the weight of the specimen in the oven-dry state divided by the volume at saturation MC. The hygroscopicity was calculated as the variation in air-dry density corresponding to a variation of $1 \% \mathrm{MC}$.

An analysis of the variance considering the presence/absence of blue stain as a factor was performed to determine possible differences between means of physical properties at $\alpha=0.05$ or 0.01 . The differences were averaged for the twenty discs, and expressed in absolute value and as a percentage of the mean for the whole sample. All statistical analyses were performed by Microsoft Excel 2003 (Microsoft Corporation, Redmond, WA, USA) and SPSS Statistics (version 20) software (IBM, Armonk, NY, USA).

\section{Results and discussion}

\section{Basic descriptive statistics}

Specimens in which both ends were completely stained $\left(\mathrm{W}_{\text {stained }}\right)$ or completely free of stain $\left(\mathrm{W}_{\text {not st. }}\right)$ (without taking into account the intensity or colour of the stain) were tested. The rate of spread of the stain was variable and very high in most cases. Therefore, in some discs the number of $\mathrm{W}_{\text {not st. }}$ was not sufficient for statistically reliable comparisons with $\mathrm{W}_{\text {stained}}$, and these discs were excluded from the analyses. As a result, the number of valid discs per tree was not always sufficient to enable sampling every metre to a height of six metres in the stem (Table 1).

Mean annual growth ring width was similar to that reported in other studies (Fernández-Golfín Seco 1996) (Table 2). The sampled wood was light, moderately stable and had an intermediate hygroscopicity, according to the standard UNE 56540:1978 (AENOR 1978b). The fibre saturation point

Table 1 Characteristics of sampled trees.

\begin{tabular}{|c|c|c|c|c|c|c|}
\hline Geographical origin & Tree \# & $\begin{array}{r}\text { Age of tree } \\
\text { (year) }\end{array}$ & $\mathrm{BH}^{\mathrm{a}}$ diam. $(\mathrm{cm})$ & Total height (m) & $\begin{array}{r}\text { No. of discs } \\
\text { per tree }\end{array}$ & $\begin{array}{r}\text { No. of specimens } \\
\text { per disc }\end{array}$ \\
\hline \multirow[t]{2}{*}{ Feás } & 1 & 9 & 10.2 & 10.1 & 5 & 10 \\
\hline & 2 & 12 & 10.6 & 9.9 & 1 & 8 \\
\hline \multirow[t]{3}{*}{ Xanceda } & 3 & 12 & 13.8 & 13.3 & 3 & 8 \\
\hline & 4 & 13 & 15.6 & 14.3 & 1 & 18 \\
\hline & 5 & 13 & 14.7 & 12.5 & 5 & 15 \\
\hline Quindimil & 6 & 14 & 13.5 & 12.4 & 4 & 11 \\
\hline Palas de Rey & 7 & 19 & 16.4 & 11.4 & 1 & 43 \\
\hline
\end{tabular}

${ }^{\mathrm{a}} \mathrm{BH}$ : breast height; ${ }^{\mathrm{b} T h e}$ mean number of specimens per disc represents the number evaluated for each property for both stained and unstained material. 
Table 2 Basic descriptive statistics of the physical properties of wood from $P$. radiata ( $n=260$ specimens). $C V=$ coefficient of variation.

\begin{tabular}{|c|c|c|c|c|c|}
\hline Variable & Abbr. & Mean & CV (\%) & Min. & Max. \\
\hline \multicolumn{6}{|l|}{ All specimens } \\
\hline Ring width (mm) & $a$ & 5.9 & 35 & 1.8 & 11.2 \\
\hline Air-dry density $\left(\mathrm{kg} \mathrm{m}^{-3}\right)$ & $\rho_{12}$ & 460 & 12 & 340 & 639 \\
\hline Oven-dry density $\left(\mathrm{kg} \mathrm{m}^{-3}\right)$ & $\rho_{0}$ & 425 & 12 & 315 & 591 \\
\hline Basic density $\left(\mathrm{kg} \mathrm{m}^{-3}\right)$ & $d_{b}$ & 379 & 11 & 289 & 535 \\
\hline Volumetric shrinkage (\%) & $C_{v}$ & 12.0 & 19 & 6.3 & 18.3 \\
\hline Volum. shrinkage coef. (\%) & $v$ & 0.36 & 26 & 0.16 & 0.71 \\
\hline Hygroscopicity $\left(\mathrm{kg} \mathrm{m}^{-3}\right)$ & $h i$ & 2.9 & 17 & 1.5 & 4.4 \\
\hline $\mathrm{FSP}_{\mathrm{vol}}(\%)^{\mathrm{a}}$ & $p s f_{v}$ & 35 & 24 & 15 & 62 \\
\hline $\mathrm{FSP}_{\text {axial }}(\%)$ & $p s f_{l}$ & 32 & 58 & 10 & 99 \\
\hline Axial shrinkage (\%) & $C_{1}$ & 0.6 & 82 & 0.0 & 2.2 \\
\hline Axial shrinkage coef. (\%) & $l$ & 0.02 & 102 & 0.00 & 0.10 \\
\hline \multicolumn{6}{|l|}{ Stained wood } \\
\hline Ring width (mm) & $a$ & 5.5 & 41 & 1.8 & 11.2 \\
\hline Air-dry density $\left(\mathrm{kg} \mathrm{m}^{-3}\right)$ & $\rho_{12}$ & 456 & 13 & 340 & 585 \\
\hline Oven-dry density $\left(\mathrm{kg} \mathrm{m}^{-3}\right)$ & $\rho_{0}$ & 424 & 13 & 315 & 546 \\
\hline Basic density $\left(\mathrm{kg} \mathrm{m}^{-3}\right)$ & $d_{b}$ & 376 & 12 & 289 & 495 \\
\hline Volumetric shrinkage (\%) & $C_{v}$ & 12.5 & 16 & 8.3 & 17.1 \\
\hline Volum. shrinkage coef. (\%) & $v$ & 0.37 & 20 & 0.19 & 0.62 \\
\hline Hygroscopicity $\left(\mathrm{kg} \mathrm{m}^{-3}\right)$ & $h i$ & 2.9 & 15 & 1.7 & 3.7 \\
\hline $\mathrm{FSP}_{\text {vol }}(\%)^{\mathrm{a}}$ & $p s f_{v}$ & 35 & 19 & 18 & 53 \\
\hline $\mathrm{FSP}_{\text {axial }}(\%)$ & $p s f_{l}$ & 32 & 58 & 10 & 89 \\
\hline Axial shrinkage (\%) & $C_{l}$ & 0.7 & 84 & 0.0 & 2.2 \\
\hline Axial shrinkage coef. (\%) & $l$ & 0.02 & 97 & 0.00 & 0.10 \\
\hline \multicolumn{6}{|l|}{ Non stained wood } \\
\hline Ring width (mm) & $a$ & 6.1 & 31 & 2.4 & 10.8 \\
\hline Air-dry density $\left(\mathrm{kg} \mathrm{m}^{-3}\right)$ & $\rho_{12}$ & 462 & 12 & 353 & 639 \\
\hline Oven-dry density $\left(\mathrm{kg} \mathrm{m}^{-3}\right)$ & $\rho_{0}$ & 425 & 12 & 323 & 591 \\
\hline Basic density $\left(\mathrm{kg} \mathrm{m}^{-3}\right)$ & $d_{b}$ & 380 & 11 & 294 & 535 \\
\hline Volumetric shrinkage (\%) & $C_{v}$ & 11.7 & 20 & 6.3 & 18.3 \\
\hline Volum. shrinkage coef. (\%) & $v$ & 0.36 & 28 & 0.16 & 0.71 \\
\hline Hygroscopicity $\left(\mathrm{kg} \mathrm{m}^{-3}\right)$ & hi & 2.9 & 19 & 1.5 & 4.4 \\
\hline $\mathrm{FSP}_{\mathrm{vol}}(\%)^{\mathrm{a}}$ & $p s f_{v}$ & 35 & 26 & 15 & 62 \\
\hline $\mathrm{FSP}_{\text {axial }}(\%)$ & $p s f_{l}$ & 32 & 58 & 10 & 99 \\
\hline Axial shrinkage (\%) & $C_{l}$ & 0.6 & 80 & 0.0 & 2.2 \\
\hline Axial shrinkage coef. (\%) & $l$ & 0.02 & 104 & 0.00 & 0.10 \\
\hline
\end{tabular}

aFSP: Fibre saturation point

(FSP) was intermediate according to the interpretation of Gutiérrez and Plaza (1967). The dimensional stability of wood was as expected because of its low density based upon the constants proposed by Koehler (1931). These results correspond to a sample of trees where sapwood was the main constituent because of the young age of the trees.

There was a high degree of variation in the properties related to dimensional stability of wood in the grain direction, namely L (axial) shrinkage, L shrinkage coefficient, and $\mathrm{FSP}_{\text {axial }}$. This is also to be expected in young trees that include a large proportion of juvenile wood, in which axial stability is very variable (Zobel and Van Buijtenen 1989; Riesco and Díaz 2007; Forest Products Laboratory 2010).

\section{Influence of blue stain on plysical properties}

Data from each disc for each physical property were subjected to an Analysis of Variance (ANOVA) with presence/ absence of blue stain as a factor. There were no significant differences in mean ring width (Table 3) and therefore significant differences for other variables were not attributable to an indirect effect of ring width variation.

In general, blue-stain fungi had minimal influence on physical properties of wood (Table 2). Only nine of the 20 sampled discs yielded significant differences between $\mathrm{W}_{\text {stained }}$ and $\mathrm{W}_{\text {not st. }}$ for the physical variables analysed (Table 3). Although the number of specimens was not the same in all the discs (Table 1), the sample size had no significant effect on results.

Density appeared to vary significantly in only five of the 20 sampled discs. The differences tended to be small and not biologically significant. $\mathrm{W}_{\text {stained }}$ was somewhat lighter than $\mathrm{W}_{\text {not st: }}$ : mean differences of $50 \mathrm{~kg} \mathrm{~m}^{-3}$ (air-dry density), $18 \mathrm{~kg} \mathrm{~m}^{-3}$ (oven-dry density) and $28 \mathrm{~kg} \mathrm{~m}^{-3}$ (basic density) were significant. Similar results were reported by Chapman and Scheffer (1940) with wood of south yellow pines of United States, Aufsess (1981) for Abies alba Mill., Schirp et al. (2000) for P. radiata or Rey Prieto and Riesco Muñoz (2012) with Pinus sylvestris L. Air-dry and basic density were $1.1 \%$ lower in $\mathrm{W}_{\text {stained }}$ (Figure 1 ), while oven-dry density was $0.5 \%$ lower in $\mathrm{W}_{\text {stained }}$ (Table 4). The variation was similar to that cited by Schirp et al. (2000), in wood of $P$. radiata inoculated with fungi of genus Ophiostoma.

Hygroscopicity was only significantly different in two discs (Table 3) and the difference was 3.4\% of the mean of the sample (Table 4). These results contradict reports on the influence of blue stain on this variable. Volumetric shrinkage was significantly different in more discs than any other wood property (Table 3). The volumetric shrinkage was $5 \%$ higher in $\mathrm{W}_{\text {stained }}$ (Figure 1 and Table 4). Despite the slight influence of blue stain on volume stability, axial shrinkage was $16.7 \%$ lower in $\mathrm{W}_{\text {stained }}$, although the differences were only significant in one disc.

The nine discs exhibited significant differences in their physical properties in terms of blue stain as a parameter (Table 3). The differences are visible at the different heights in the stem and at the five trees that differ in size, age and stand. The discs from less than $2 \mathrm{~m}$ above ground exhibited more significant differences in basic density between $\mathrm{W}_{\text {stained }}$ and $\mathrm{W}_{\text {not st }}$. Physical properties in subsamples $\left(\mathrm{W}_{\text {stained }}\right.$ and $\left.\mathrm{W}_{\text {not st. }}\right)$ differed significantly in the youngest and tallest trees with the greatest slenderness. As slenderness disappears with age (on the small sample analysed), these differences were expected to diminish with the tree age. 
Table 3 Mean values of unstained and stained specimens with P-values (top, centre and bottom of each cell, respectively) obtained in the analysis of the variance for each physical property of wood of $P$. radiata in presence or absence of blue stain as a factor. ns=not significant. For abbreviations see Table 2. Only results for discs exhibiting significant differences ( $P$-value $<0.050)$ for at least one of the variables are presented.

\begin{tabular}{|c|c|c|c|c|c|c|c|c|c|}
\hline \multirow[t]{2}{*}{ Variable } & \multirow[b]{2}{*}{$\# 1,0 \mathrm{~m}$} & \multirow[b]{2}{*}{$\# 1,4 \mathrm{~m}$} & \multirow[b]{2}{*}{$\# 3,4 \mathrm{~m}$} & \multirow[b]{2}{*}{$\# 4,0 \mathrm{~m}$} & \multicolumn{5}{|c|}{ Number of tree in Table 1 (\#) and height of the disc in the stem (m) } \\
\hline & & & & & \#5, $1 \mathrm{~m}$ & $\# 5,2 \mathrm{~m}$ & $\# 6,0 \mathrm{~m}$ & \#6, $1 \mathrm{~m}$ & \#6, $6 \mathrm{~m}$ \\
\hline$a$ & ns & ns & ns & ns & ns & ns & ns & ns & ns \\
\hline \multirow[t]{3}{*}{$\rho_{12}$} & ns & ns & ns & 589 & ns & ns & 500 & 481 & ns \\
\hline & & & & 542 & & & 453 & 427 & \\
\hline & & & & 0.013 & & & 0.015 & 0.010 & \\
\hline \multirow[t]{3}{*}{$\rho_{0}$} & 424 & 339 & ns & 547 & ns & ns & 464 & 449 & ns \\
\hline & 447 & 360 & & 508 & & & 421 & 397 & \\
\hline & 0.026 & 0.014 & & 0.024 & & & 0.022 & 0.008 & \\
\hline \multirow[t]{3}{*}{$d_{b}$} & 379 & ns & ns & 493 & ns & ns & 411 & 396 & ns \\
\hline & 400 & & & 445 & & & 370 & 352 & \\
\hline & 0.022 & & & 0.007 & & & 0.010 & 0.010 & \\
\hline \multirow[t]{3}{*}{$C_{v}$} & ns & 6.8 & 8.8 & 11.0 & 10.8 & 10.5 & ns & ns & 11.9 \\
\hline & & 9.4 & 10.5 & 14.1 & 13.7 & 12.8 & & & 8.6 \\
\hline & & 0.040 & 0.015 & 0.000 & 0.000 & 0.044 & & & 0.022 \\
\hline \multirow[t]{3}{*}{$v$} & ns & ns & ns & 0.36 & 0.26 & 0.23 & ns & ns & 0.38 \\
\hline & & & & 0.42 & 0.37 & 0.32 & & & 0.30 \\
\hline & & & & 0.032 & 0.003 & 0.022 & & & 0.021 \\
\hline \multirow[t]{3}{*}{$h i$} & ns & ns & ns & 3.79 & ns & ns & 3.3 & ns & ns \\
\hline & & & & 3.13 & & & 2.9 & & \\
\hline & & & & 0.003 & & & 0.019 & & \\
\hline \multirow[t]{3}{*}{$p s f_{v}$} & ns & ns & 27 & ns & ns & ns & ns & ns & ns \\
\hline & & & 33 & & & & & & \\
\hline & & & 0.004 & & & & & & \\
\hline$p s f_{l}$ & ns & ns & ns & ns & ns & ns & ns & ns & ns \\
\hline \multirow[t]{3}{*}{$C_{1}$} & ns & 0.44 & ns & ns & ns & ns & ns & ns & ns \\
\hline & & 0.13 & & & & & & & \\
\hline & & 0.008 & & & & & & & \\
\hline \multirow[t]{3}{*}{$l$} & ns & 0.02 & ns & ns & ns & ns & ns & ns & 0.02 \\
\hline & & 0.00 & & & & & & & 0.04 \\
\hline & & 0.018 & & & & & & & 0.019 \\
\hline
\end{tabular}
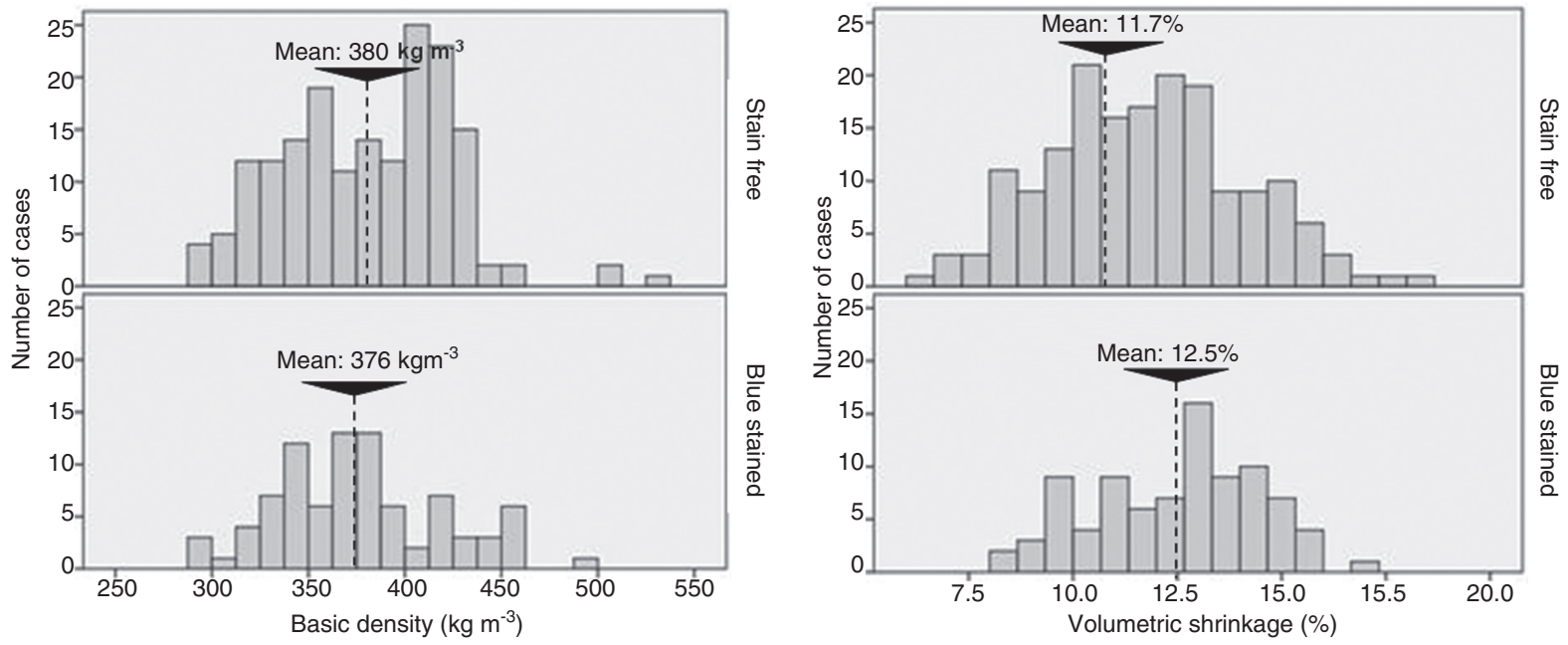

Figure 1 Effect of blue stain on the variations in basic density and volumetric shrinkage in the whole sample of wood of $P$. radiata (20 discs). 
Table 4 Differences in physical properties of blue-stained wood of $P$. radiata with reference to stain-free wood for the whole sample; $n=20$ discs; 13 specimens per disc on average.

\begin{tabular}{lrr}
\hline Variable & \multicolumn{2}{c}{ Mean decrease in stained wood } \\
\cline { 2 - 3 } & Absolute & (\%) \\
\hline Ring width (mm) & 0.3 & 5.1 \\
Air-dry density (kg m$\left.{ }^{-3}\right)$ & 5 & 1.1 \\
Oven-dry density $\left(\mathrm{kg} \mathrm{m}^{-3}\right)$ & 2 & 0.5 \\
Basic density (kg m$\left.{ }^{-3}\right)$ & 4 & 1.1 \\
Vol. shrinkage (\%) & -0.6 & -5.0 \\
Vol. shrinkage coef. (\%) & -0.02 & -5.6 \\
Hygroscopicity (kg m$\left.{ }^{-3}\right)$ & 0.1 & 3.4 \\
FSP $_{\text {vol }}$ (\%) & 0 & 0.0 \\
FSP $_{\text {axial }}$ (\%) & -4 & -12.5 \\
Axial shrinkage (\%) & 0.1 & 16.7 \\
Axial shrinkage coef. (\%) & 0.00 & 0.0 \\
\hline
\end{tabular}

\section{Conclusions}

The results confirm the generally accepted view that blue-stain fungi have minimal effects on physical properties of wood. This was also the case for young radiata pines. Blue-stain mostly influenced density and volume stability. Blue-stained wood $\left(\mathrm{W}_{\text {stained }}\right)$ was slightly lighter than in $\mathrm{W}_{\text {not st. }}$, while volumetric shrinkage was higher in $\mathrm{W}_{\text {stained }}$. The differences in physical properties due to blue stain were only significant in some trees and in some parts of the stems, i.e., mainly in basal logs of the youngest trees with the greatest slenderness. Very few discs exhibited significant differences in variables related to axial shrinkage due to blue stain. Further studies should focus on adult trees to verify the lowering tendency of blue stain attack with age as indicated in the present study.

\section{References}

AENOR (1977a) UNE 56531:1977. Determinación del peso específico. Asociación Española de Normalización y Certificación, Madrid.

AENOR (1977b) UNE 56532:1977. Determinación de la higroscopicidad. Asociación Española de Normalización y Certificación, Madrid.

AENOR (1977c) UNE 56533:1977. Determinación de las contracciones lineal y volumétrica. Asociación Española de Normalización y Certificación, Madrid.

AENOR (1978a) UNE 56528:1978. Preparación de probetas para ensayos. Asociación Española de Normalización y Certificación, Madrid.

AENOR (1978b) UNE 56540:1978. Interpretación de los resultados de los ensayos. Asociación Española de Normalización y Certificación, Madrid.
AENOR (2008) UNE-EN 1927-2:2008. Clasificación de calidad de la madera en rollo de coníferas. Parte 2: Pinos. Asociación Española de Normalización y Certificación, Madrid.

AENOR (2011) UNE 56544:2011. Clasificación visual de la madera aserrada para uso estructural. Madera de coníferas. Asociación Española de Normalización y Certificación, Madrid.

Aufsess, H.V. (1981) Effects of silver fir dieback on the wood properties of affected trees. Forstwissenschaftliches Centralblatt. 100:217-228.

Byrne, T., Woo, K.L., Uzunovic, A., Watson, P.A. An annotated bibliography on the effect of bluestain on wood utilization with emphasis on mountain pine beetle-vectored bluestain. Working Paper 2005-4. Canadian Forest Service, Victoria, 2005.

Chapman, A.D., Scheffer, T.C. (1940) Effect of bluestain on specific gravity and strength of southern pine. J.Agric.Res. 61:125-133.

European Committee for Standardization (2002) EN 13183-1:2002. Moisture content of a piece of sawn timber - Part 1: Determination by oven dry method.

European Committee for Standardization (2010) EN 384:2010. Structural timber. Determination of characteristic values of mechanical properties and density.

European Committee for Standardization (2011) EN 408:2011. Timber structures. Structural timber and glued laminated timber. Determination of some physical and mechanical properties.

Fernández-Golfín Seco, J.I. Manual de usuario pino insignis del País Vasco. Centro Técnico de la Madera, ZTB, Vitoria, 1996.

Forest Products Laboratory. Wood handbook. Wood as an engineering material. General Technical Report FPL-GTR-190. U.S. Department of Agriculture, Forest Service, Forest Products Laboratory, Madison, 2010.

Ghosh, S.C., Dyckmans, J., Militz, H., Mai, C. (2012) Effect of quatand amino-silicones on fungal colonisation and decay of wood. Holzforschung 66:1009-1015.

Gradinger, C., Boisselet, T., Stratev, D., Ters, T., Messner, K., Fackler, K. (2009) Biological control of sapstain fungi: From laboratory experiments to field trials 10th EWLP, Stockholm, Sweden, August 25-28, 2008. Holzforschung 63:751-759.

Gutiérrez, A., Plaza, F. Características físico-mecánicas de las maderas españolas. Instituto Forestal de Investigaciones y Experiencias, Madrid, 1967.

Hong, J.H., Lee, J., Min, M., Ryu, S.M., Lee, D., Kim, G.H., Kim, J.J. (2014) 6-Pentyl- $\alpha$-pyrone as an anti-sapstain compound produced by Trichoderma gamsii KUC1747 inhibits the germination of ophiostomatoid fungi. Holzforschung 68:769-774.

International Organization for Standardization (1975) ISO 3131:1975. Wood. Determination of density for physical and mechanical tests.

Jayawickrama, K.J.S. (2001) Breeding radiata pine for wood stiffness: review and analysis. Austral. For. 64:51-56.

Kininmonth, J.A., Whitehouse, L.J. Properties and uses of New Zealand radiata pine (vol. I, Wood properties). Ministry of Forestry, FRI, Christchurch, 1991.

Koehler, A. (1931) Longitudinal shrinkage of wood. Transactions of the American Society of Mechanical Engineers. 53: 17-20. 
Kollmann, F. Tecnología de la madera y sus aplicaciones (vol. I). Instituto Forestal de Investigaciones y Experiencias, Madrid, 1959.

McFarling, S., Byrne, A. Characterizing the dimensional stability, checking, and permeability of wood containing beetletransmitted bluestain. Report to Forest Innovation Investment. Forintek Canada Corp., Vancouver, 2003.

Rey Prieto, A., Riesco Muñoz, G. (2012) Influencia del azulado (mancha azul) en la densidad y estabilidad dimensional de la madera de Pinus sylvestris. Maderas-Cienc. Tecnol. 14:115-125.

Riesco, G., Díaz, J. (2007) Características físicas de la madera de pino procedente de raleos en el noroeste de España. Maderas-Cienc. Tecnol. 9:233-244.
Rodríguez, J., Arriaga, F. (1988) Patología de la madera. In: Curso de Construcción en Madera. Eds. Colegio Oficial de Arquitectos de Madrid, Madrid. pp. 205-236.

Schirp, A., Farrell, R.L., Kreber, B. (2000) Capability of staining fungi to cause structural changes in New Zealand radiata pine: toughness testing and enzyme production. Maderas-Cienc. Tecnol. 2:119-129.

Torres Juan, J. El azulado de la madera y su tratamiento. AITIM, Madrid, 1964.

Vignote, S., Martínez, I. Tecnología de la madera. Mundi-Prensa, Madrid, 2006.

Zobel, B.J., Van Buijtenen, J.P. Wood variation. Its causes and control. Springer Verlag, Berlin, 1989. 